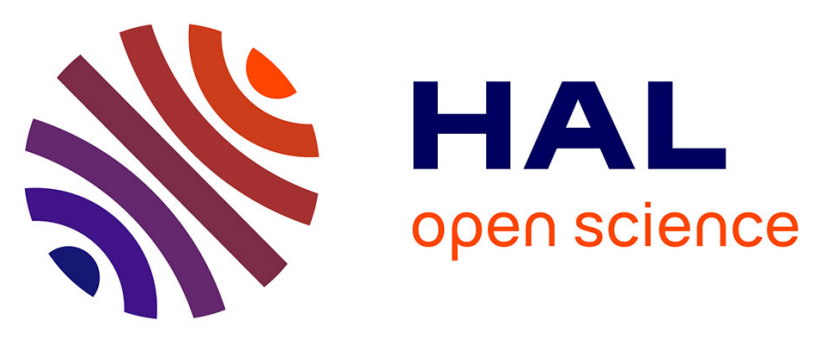

\title{
Cytomegalovirus associated hemophagocytic lymphohistiocytosis in patients suffering from crohn's disease treated by azathioprine: A series of four cases
}

Yohan N'guyen, Sonia Baumard, Jean Hugues Salmon, Louis Lemoine, Nicolas Lévêque, Amélie Servettaz, Roland Jaussaud, Christophe Strady, Laurent Andreoletti

\section{To cite this version:}

Yohan N'guyen, Sonia Baumard, Jean Hugues Salmon, Louis Lemoine, Nicolas Lévêque, et al.. Cytomegalovirus associated hemophagocytic lymphohistiocytosis in patients suffering from crohn's disease treated by azathioprine: A series of four cases. Inflammatory Bowel Diseases, 2011, 17 (9), pp.E116 - E118. 10.1002/ibd.21770 . hal-03267108

\section{HAL Id: hal-03267108 \\ https://hal.science/hal-03267108}

Submitted on 22 Jun 2021

HAL is a multi-disciplinary open access archive for the deposit and dissemination of scientific research documents, whether they are published or not. The documents may come from teaching and research institutions in France or abroad, or from public or private research centers.
L'archive ouverte pluridisciplinaire HAL, est destinée au dépôt et à la diffusion de documents scientifiques de niveau recherche, publiés ou non, émanant des établissements d'enseignement et de recherche français ou étrangers, des laboratoires publics ou privés. 
Cytomegalovirus

Associated

Hemophagocytic

Lymphohistiocytosis in

Patients Suffering from

Crohn's Disease Treated

by Azathioprine: A Series

of Four Cases

\section{To the Editor:}

We report here a series of human cytomegalovirus (HCMV)-related hemophagocytic lymphohistiocytosis (HLH) cases (HCMV-HLH) that occurred during the 2009-2010 period in four female patients age $32.2 \pm 3.7$ years suffering from Crohn's disease (CD). Azathioprine was the current treatment for all of them, whereas two had received antitumor necrosis factor (TNF) (Table 1).

Fever, cytopenia, hyperferritinemia, and hypertriglyceridemia were present in all cases. Bone marrow aspiration showed macrophagic hyperplasia and erythrophagocytosis in each case and the diagnosis of HLH was established using the referenced clinical and biological parameters as described in Table 1. ${ }^{1}$ A mild $2 \mathrm{~N}$ transaminases elevation with hyperbasophilic mononuclear cells on complete blood count was present in all of these cases. HCMV plasma viral load and $\mathrm{IgG}$ and IgM serologies were positive for each patient, with a low IgG avidity index supporting a HCMV primo-infection (Table 1). Moreover, no other relevant infectious (Mycobacterium tuberculosis, Mycoplasma pneumoniae, Epstein

Supported in part by a grant for Clinical and Virological Research (IFR53/EA-4303) from the Medical University and School of Medicine of Reims, France.

Copyright (C) 2011 Crohn's \& Colitis Foundation of America, Inc.

DOI 10.1002/ibd. 21770 Published online 24 January 2011 in Wiley Online Library (wileyonlinelibrary.com).
Barr virus, Herpes simplex, etc.) or noninfectious etiological causes (lymphoma, etc. $)^{2}$ were seen in the study patients (not shown).

All four patients received corticoids and an antiviral therapy (ganciclocir and/or valganciclovir), whereas azathioprine and anti-TNF were withdrawn at the time of hospitalization (Table 1). The clinical course was good for two patients (Cases 1 and 2) with apyrexia, cytopenia resolution, and an undetectable HCMV peripheral blood plasma viral load $(<500$ genome copies/mL) 15 days later. For Cases 1 and 2, corticotherapy and antiviral therapy were discontinued at 6 and 4 months, respectively. Moreover, these patients received an anti-TNF in association with antiviral therapy that was introduced or reintroduced without HCMV-HLH relapse at 2 and 3 months, respectively. For these two patients, the clinical outcome was good 21 and 15 months later.

A pericarditis with tamponade and an acute colitis due to CD and HCMV infection was diagnosed in Case 3 and a bilateral HCMV pneumoniae was evident in Case 4 (HCMV bronchoalveolar lavage viral load 19200 copies/mL without any other relevant pathogen seen by classical and molecular microbiological techniques). These two patients required intensive care unit admission. An absence of favorable hematologic response with corticosteroids required the introduction of polyvalent immunoglobulins and foscarnet antiviral therapies in both Cases 3 and 4. Total colectomy was performed in Case 3, whereas an emergency surgery related to the perforation of two necrotic gastric ulcers was necessary in Case 4. The clinical outcome was good 9 months later for Patient 3, whereas Patient 4 died during emergency surgery.

We report the largest monocentric series of $\mathrm{CD}$ patients experiencing HCMV-HLH. All of our patients were female, which might be due to the sex ratio of 1.3 female to 1 male for $\mathrm{CD}$ patients in northern France. ${ }^{3}$ The occurrence of these four study cases over a short period could be explained by the fact that all CD patients treated by azathioprine hospitalized for unexplained fever and cytopenia were not systematically considered for azathioprine toxicity and therefore were also screened for HLH by ferritinemia, triglyceridemia, and then in cases of abnormal values by a bone marrow aspiration. This approach was systematically conducted in order to obtain a sufficient number of diagnostic criteria. ${ }^{1}$ In cases of histological confirmation of HLH, real-time polymerase chain reaction (PCR) techniques for the detection of an ongoing human herpesviridae infection were performed. ${ }^{4} \mathrm{HCMV}$ is recognized to be one of the main infectious causes of $\mathrm{HLH}$ in adult CD patients ${ }^{4-6}$ with Epstein Barr virus ${ }^{7}$ and Mycobacterium tuberculosis. ${ }^{5}$ Because all of the patients experienced azathioprine during the years before, and that only two of them had been previously treated by anti-TNF for a shorter period, we suspected a potential role of azathioprine treatment in the genesis of HCMVHLH. Moreover, anti-TNF treatment was reintroduced in Patients 1 and 2 without HCMV-HLH relapse, supporting the hypothesis of a nondeleterious role of anti-TNF in the course of the HCMV-related HLH in these patients. Further larger prospective and multicentric studies would be necessary to investigate the potential deleterious role of azathioprine compared to that of anti-TNF treatment in the development of HCMV-HLH in patients with $\mathrm{CD}$. In the present report, neither azathioprine treatment length nor HCMV plasma viral load levels appeared to be potentially related to a worse prognosis in HCMV-HLH (Table 1). Moreover, the prognosis of focal organ damage such as pericarditis, colitis, or pneumonia and the clinical significance of persistent high ferritinemia values during the course of the $\mathrm{HLH}^{8}$ remain to be 
TABLE 1. Demographic Clinical and Biological Characteristics of the Four Study HCMV-HLH Patients

\begin{tabular}{|c|c|c|c|c|}
\hline & Case 1 & Case 2 & Case 3 & Case 4 \\
\hline $\operatorname{Sex}(M / F)$ & $\mathrm{F}$ & $\mathrm{F}$ & $\mathrm{F}$ & $\mathrm{F}$ \\
\hline Age (years) & 28 & 33 & 30 & 38 \\
\hline \multicolumn{5}{|l|}{ Treatment received for Crohn's disease: } \\
\hline Azathioprine (length of treatment in years) & $+(5)$ & $+(5)$ & $+(4)$ & $+(2)$ \\
\hline Anti-TNF (length of treatment in years) & $+(2)$ & - & $+(0.08)$ & - \\
\hline Fever & + & + & + & + \\
\hline Lymphadenopathy & - & + & - & - \\
\hline Hepatosplenomegaly & - & - & - & - \\
\hline Pericarditis & - & - & + & - \\
\hline Colitis & - & - & + & - \\
\hline Pneumopathy & - & - & - & + \\
\hline Cytopenia & + & + & + & + \\
\hline Hyperbasophilic mononuclear cells (\% on CBC) & $+(8)$ & $+(8)$ & $+(2)$ & $+(9)$ \\
\hline Ferritinemia on admission $(>\mathbf{5 0 0} \mathbf{~ n g} / \mathbf{m L})(\mathrm{N}<190 \mathrm{ng} / \mathrm{mL})$ & 2380 & 2100 & 4020 & 22400 \\
\hline Maximal ferritinemia during hospitalization $(\mathrm{N}<190 \mathrm{ng} / \mathrm{mL})$ & 2380 & 2100 & 4170 & 52900 \\
\hline Triglyceridemia $(>\mathbf{3 . 0} \mathbf{m m o l} / \mathbf{L})(\mathrm{N}<1.71)$ & 3.16 & 3.49 & 2.32 & 5.07 \\
\hline \multicolumn{5}{|l|}{ Bone marrow aspiration } \\
\hline Macrophagic hyperplasia & + & + & + & + \\
\hline Erythrophagocytosis & + & + & + & + \\
\hline HCMV IgG serology & + & + & + & + \\
\hline HCMV IgM serology & + & + & + & + \\
\hline HCMV IgG avidity index CLIA Diasorin* & 0.19 & 0.05 & 0.18 & 0.03 \\
\hline HCMV plasma viral load (copies/mL) & 173000 & 390000 & 74600 & 154000 \\
\hline Delay between treatment and onset of disease (days) & 7 & 29 & 38 & 15 \\
\hline \multicolumn{5}{|l|}{ Therapeutic management } \\
\hline Corticotherapy & + & + & + & + \\
\hline Polyvalent Immunoglobulins & - & - & + & + \\
\hline Ganciclovir/valganciclovir & + & + & + & + \\
\hline Foscarnet & - & - & + & + \\
\hline Azathioprine withdrawal & + & + & + & + \\
\hline Anti-TNF withdrawal & + & $\mathrm{NA}^{\dagger}$ & + & NA \\
\hline Outcome & Survived & Survived & Survived & Dead \\
\hline Anti-TNF introduction without HCMV-HLH relapse & + & + & - & NA \\
\hline
\end{tabular}

CBC, complete blood count. NA, not applicable.

*CLIA Diasorin, liaison index $<0.2$ when infection occurred within the past 3 months.

Bold $=$ Criteria definition for the diagnosis of hemophagocytic syndrome ${ }^{1}$ : diagnosis is confirmed when five criteria are fulfilled and highly possible when four criteria are fulfilled.

fully investigated in further prospective larger studies.

\section{ACKNOWLEDGMENTS}

We thank all the physicians involved in the clinical and therapeutic management of the four study patients suffering from Crohn's disease, especially Dr. Farkas, Dr. Aucouturier, Dr. Carteret, Dr. Louvet, Dr. Vandromme, and Pr. Cadiot. Yohan N'Guyen, MD*, $\dagger$
Sonia Baumard, MD*
Jean Hugues Salmon, $\mathrm{SHO}^{*}$
Louis Lemoine, SHO
Nicolas Lévêque, MD, PhD,$\S$
Amélie Servettaz, MD, PhD*
Roland Jaussaud, MD, PhD*
hristophe Strady, MD, PhD*,

Christophe Strady, MD, $\mathrm{PhD}^{*}, \dagger$
Laurent Andreoletti, MD, $\mathrm{PhD}^{\dagger} \S$

* Service de Médecine interne et Maladies infectieuses (Pr Jaussaud), Hôpital Robert

Debré, Reims

France

†EA/IFR53, Faculté de médecine, Reims

France

¥Service de Réanimation Polyvalente (Pr Leon), Hôpital Robert Debré, Reims

France
§Laboratoire de virologie médicale et moléculaire (Pr Andreoletti) Hôpital Robert Debré, Reims

France

\section{REFERENCES}

1. Fardet L, Lambotte $\mathrm{O}$, Meynard JL, et al. Reactive haemophagocytic syndrome in 58 HIV-1-infected patients: clinical features, underlying diseases and prognosis. AIDS. 2010;24:1299-1306.

2. Créput C, Gallicier L, Buyse E, et al. Understanding organ dysfunction in hemophagocytic lymphohistiocytosis. Intensive Care Med. 2008;34:1177-1187.

3. Gower-Rousseau C, Salomez JL, Dupas JL, et al. Incidence of inflammatory bowel 
disease in northern France (1988-1990). Gut. 1994;35:1433-1438.

4. Kohara MM, Blum RN. Cytomegalovirus ileitis and hemophagocytic syndrome associated with use of anti-tumor necrosis factor-alpha antibody. Clin Infect Dis. 2006;42:733-734.

5. James DG, Stone CD, Wang HL, et al. Reactive hemophagocytic syndrome complicat- ing the treatment of inflammatory bowel disease. Inflamm Bowel Dis. 2006;12:573-580.

6. Miquel T, Bonnet DP, Leport J, et al. Hemophagocytic syndrome in the course of Crohn's disease: possible association with cytomegalovirus infection. Am J Gastroenterol. 2009;104:252.

7. Francolla KA, Altman A, Sylvester FA. Hemophagocytic syndrome in an adolescent with Crohn disease receiving azathioprine and infliximab. J Pediatr Gastroenterol Nutr. 2008;47:193-195.

8. Esumi N, Ikushima S, Todo $\mathrm{S}$, et al. Hyperferritinemia in malignant histiocytosis and virus associated hemophagocytic syndrome. N Engl J Med. 1986;316:346347. 